Article

\title{
Effect of Watering of Selected Seasoning Herbs with Water Treated with Low-Temperature, Low-Pressure Glow Plasma of Low Frequency
}

\author{
Katarzyna Ciesielska ${ }^{1}$, Wojciech Ciesielski ${ }^{1}{ }^{1} * \mathbb{D}$, Tomasz Girek ${ }^{1}$, Zdzisław Oszczęda ${ }^{2}$ \\ and Piotr Tomasik ${ }^{2}$ \\ 1 Institute of Chemistry, Jan Długosz University, Armii Krajowej Ave. 13-15, 42201 Częstochowa, Poland; \\ k.ciesielska@ujd.edu.pl (K.C.); t.girek@ujd.edu.pl (T.G.) \\ 2 Nantes Nanotechnological Systems, Dolnych Młynów Str. 24, 59700 Bolesławiec, Poland; \\ z.oszczeda@nantes.pl (Z.O.); rrtomasi@cyf-kr.edu.pl (P.T.) \\ * Correspondence: w.ciesielski@interia.pl
}

Received: 22 November 2020; Accepted: 12 December 2020; Published: 16 December 2020

\begin{abstract}
Plantations of lovage, marjoram, rosemary and thyme were watered with water treated with low-temperature, low-pressure glow plasma of low frequency. Such watering appeared beneficial to the extent dependent on particular herb. In terms of crop yield and quality, water treated with glow plasma performed best in the case of rosemary, and the worst results were observed for thyme. When yield of essential oils are taken into account, only in the case of lovage did such watering appear beneficial, while in the remaining cases it had no effect. However, such watering considerably changed the composition of essential oils. These changes were specific for a given herb and involved the quantity of particular components of the oils. Only in the essential oil from lovage did $\gamma$-terpinene appear as its novel component.
\end{abstract}

Keywords: essential oil; lovage; marjoram; rosemary; thyme

\section{Introduction}

Following the invention of low-temperature, low-pressure glow plasma of low frequency (LPGP) and the constructing of generators for such plasma [1,2], a series of papers was published describing the macrostructure and the resulting physical, physicochemical and chemical properties of water treated with LPGP. It appeared that these properties depended, among other things, on whether that treatment was performed in the air, under nitrogen, ammonia, carbon dioxide, methane or molecular oxygen [3-8]. Subsequent papers demonstrated that these diverse properties resulted in specific functional properties for different kinds of water. The distinct functional properties of various kinds of LPGP-treated water have been presented for lettuce and grass [9], peppermint [10], cress [11], lavender [12], basil [13] and oregano [14]. The crop quality and yield of those plants, and in case of herbs, also the yield and composition of their essential oils, changed considerably. The selection of a given kind of water for watering those herbs could be interesting for herbal medicine and aromatherapy.

Among the different kinds of LPGP-treated water production, that in the air (LPGPA) was the simplest, and hence the most economically profitable. Therefore, in this paper, the functional properties of LPGPA are investigated in the case of selected seasoning herbs. The novelty of this paper lies in improving the yield and quality of the crops of the investigated herbs by watering them with water treated with this particular glow plasma in the air. This treatment also resulted in a modified composition of the essential oils, which could be of interest for applications in herbal medicine and aromatherapy. Thus, the treated water was used to water plantations of lovage, marjoram, rosemary 
and thyme, and these results are presented in terms of the crops' quality and yield, as well as the effect upon the yield and composition of the essential oils extracted from those cultivars.

Lovage, a species from the genus Levisticum in the family Apiacea [15], is a common seasoning herb and a vegetable. Its leaves, roots and seeds are used [16]. Its roots, which contain, among other things, furanocoumarins [17], are also used as a mild aquaretic [18].

Marjoram (Origanum majorana), in the form of either green or dry leaves, is used for seasoning soups, stews, dressings, sauces, and as a herbal tea [19].

Rosemary is a member of the mint family Lamiaceae. Apart from seasoning purposes [20], it is also used as a decorative garden plant [21]. Rosemary extract improves the shelf life and heat stability of omega 3-rich oils [22]. Apart from volatile components that can be extracted into essential oil, rosemary contains several phytochemicals, such as rosmarinic, caffeic, ursolic, betulinic, and carnosic acids [21].

Thyme is a member of the genus Thymus in the mint family Laminacea. For culinary purposes, Thymus vulgaris is commonly used [23,24]. Apart from its seasoning value it is also appreciated for its antimicrobial activity [25-28].

\section{Materials and Methods}

\subsection{Materials}

\subsubsection{Herbs}

Seedlings of all four herbs were purchased from Flower Farm, Tropiszow, 131, 32-125 Wawrzeńczyce, Poland.

\subsubsection{Water}

Tap water from Bolesławiec of total hardness $129 \mathrm{mg} / \mathrm{L} \mathrm{CaCO} ; \mathrm{pH} 7.1$; conductivity $334 \mu \mathrm{S} / \mathrm{cm}$; $\mathrm{Fe}<50 \mu \mathrm{g} / \mathrm{L} ; \mathrm{Mn}<5 \mu \mathrm{g} / \mathrm{L} ;$ dissolved oxygen $6.93 \mathrm{mg} / \mathrm{L}$ was used.

\subsection{Methods}

\subsubsection{Treatment of Water with Low-Temperature, Low-Pressure Glow Plasma of Low Frequency}

Tap water $(200 \mathrm{~mL})$ in $250 \mathrm{~mL}$ polyethylene bottles was placed in the chamber of the reactor [1] and exposed to plasma for $30 \mathrm{~min}$. Plasma of $38^{\circ} \mathrm{C}$ was generated at $5 \times 10^{-3} \mathrm{mbar}, 600 \mathrm{~V}, 50 \mathrm{~mA}$ and $280 \mathrm{GHz}$ frequency. The produced water was stored at ambient temperature in $100 \mathrm{~mL}$ closed Teflon containers.

\subsubsection{Substrate}

Substrate was composed of medium size turf fraction Florabalt ${ }^{\circledR}$ Pot Medium-Coarse (Floragard, Oldenburg, Federal Republic of Germany). The medium of pH 5.6, contained $1.2 \mathrm{~g} / \mathrm{L}$ total salts including $210 \mathrm{mg} \mathrm{N} / \mathrm{L}, 120 \mathrm{mg} \mathrm{P}_{2} \mathrm{O}_{5} / \mathrm{L}, 260 \mathrm{mg} \mathrm{K} 2 \mathrm{O} / \mathrm{L}$. It was supplemented with multicomponent PG-Mix 18-10-20 fertilizer $\left(1.20 \mathrm{~kg} / \mathrm{m}^{3}\right)$ (Yara, Oslo, Norway).

\subsubsection{Trays}

QP 15RW multiplates QP 15RW trays (Herkuplast Kubern GmbH, Ering/Inn, Federal Republic of Germany) were used. Each multiplate consisted of $3 \times 5$ trays. Each tray had a capacity of $280 \mathrm{~cm}^{3}$. A $1 \mathrm{~m}^{2}$ area of greenhouse hosted 880 plants.

\subsubsection{Herb Plantation}

The monofactorial experiment was carried out from 24 February (sowing) until 18 May (harvesting) 2019 in a greenhouse at the University of Agriculture in Cracow. The temperature in the greenhouse was set for 22 and $18{ }^{\circ} \mathrm{C}$ during the day and night, respectively. The day time lasted $16 \mathrm{~h}$ after sunup. 
The passing from the day regime into the night regime was controlled by computer. Automatic additional illumination with sodium lamps was used for $16 \mathrm{~h}$ when the natural light intensity fell to below $100 \mathrm{~W} / \mathrm{m}^{2}$. The experiment involved three sets of trays with 24 pots each. Ten seeds of basil were sown into every pot. In one series of experiments, two multiplates hosted 300 plants. To eliminate the parietal effect, 60 plants on the edge of trays were left apart, and therefore, only 240 plants were harvested. Since the experiments were run in triplicate, a maximum of 720 plants were collected for a given series.

The watering was adjusted according to tensiometer readings (Irrometer model SR $150 \mathrm{~mm}$ ) when soil water tension was $<-40 \mathrm{kPa}$. The plants were watered by hand to avoid the accidental contact of water with leaves. Initially, the plants consumed a total of $3 \mathrm{~L}$ water, that is, $1 \mathrm{~L}$ for each replicate in the 5-day period until 24 March. In the subsequent 1-month period, the watering was intensified, and the same amount of water was administered to the plants in 3-day periods. In the final period of breading, the plants were watered daily, consuming the same amount of water. In this manner, the watering consumed a total of $40 \mathrm{~mL}$ each kind of water daily. The experiment was terminated on 18 May, when the plants were collected. The plants were then dried at $105^{\circ} \mathrm{C}$ for $4 \mathrm{~h}$ to determine the dry mass of the crops.

\subsubsection{Ash}

In a vessel weighed with $0.0002 \mathrm{~g}$ precision, a substance was weighed with the same precision and the whole was inserted for $10 \mathrm{~min}$ into the front of an oven heated to $815^{\circ} \mathrm{C}$. Subsequently, the vessel with the sample was shifted $(2 \mathrm{~cm} / \mathrm{min})$ into the central region of the chamber. After returning the temperature of the oven to $815^{\circ} \mathrm{C}$, the analyzed sample was maintained inside the chamber for a further $25 \mathrm{~min}$. After that time, the sample was left in the open for cooling to room temperature, and then weighed with a $0.0002 \mathrm{~g}$ precision.

\subsubsection{Humidity and Final Mass of Plants}

Humidity and final mass of plants were determined with a RADWAG MA 50. R balance-dryer (Radom, Poland) with a precision of $0.01 \mathrm{mg}$.

\subsubsection{Condition of Plants}

Photographs were taken after 6 weeks of breeding using a NIKON COOLPIX P1000 apparatus.

\subsubsection{Separation of Essential Oils for Determination of Their Yield}

Samples of the plant (100 g) were steam distilled in a Deryng apparatus with a closed water circulation. The collected oils were transferred to a closed vials.

\subsubsection{Gas Chromatographic Analyses}

Sample $(5 \mu \mathrm{L})$ was transferred to closed chromatographic viol and evaporated on a heating plate. Using gas-tight syringe gaseous sample $(10 \mu \mathrm{L})$ was analyzed using a Bruker 436-GC gas chromatograph coupled with Bruker SCION SQ (single quadruple, electron ionization) mass spectrometer (Durham, UK). The estimations were duplicated.

The instrument was equipped with BR-5 ms; $0.25 \mathrm{~nm} \times 30 \mathrm{~m}, \mathrm{df}=0.25 \mu \mathrm{m}$. The column operated at the following temperature schedule: $50{ }^{\circ} \mathrm{C}(2 \mathrm{~min})$ at the temperature rate increase $10{ }^{\circ} \mathrm{C} / \mathrm{min}$ up to $170{ }^{\circ} \mathrm{C}(0 \mathrm{~min})$, then at $25^{\circ} \mathrm{C}$ to $280{ }^{\circ} \mathrm{C}(5 \mathrm{~min})$. The dispenser, transfer line and source temperatures were 300,280 and $200{ }^{\circ} \mathrm{C}$, respectively. Sample separation was set for 1:20, helium was used as the carrier gas. The flow of the mobile phase was $1.0 \mathrm{~mL} / \mathrm{min}$, and ionization energy was $70 \mathrm{keV}$. Scanning was performed in the $50-500 \mathrm{~m} / \mathrm{z}$ range. 
Chromatographic signals were identified by comparison with mass spectra available in the National Institute of Standards and Technology (NIST) 11 library. Area under particular chromatographic peaks were calculated involving computer program installed in the chromatograph.

\subsection{Statistics}

The results were subjected to statistical interpretation, mean values and standard errors were calculated, and the significance of the variables was determined. Statistically significant differences between means $(p<0.05)$ were evaluated using one-way analysis of variance (ANOVA) with a post hoc multiply Duncan's range test [29]. Moreover, the Pearson product-moment correlation coefficients between analyzed variables were calculated. The significance level for correlation coefficient was $p=0.05$, and the number of pairs for the calculations was $\mathrm{N}=216$. All statistical analyses were calculated using Statistica 13.3 software (Tibco Software Inc., Palo Alto, CA, USA).

\section{Results and Discussion}

Figure 1 shows that watering four investigated herbs with LGPGA promoted their growth.
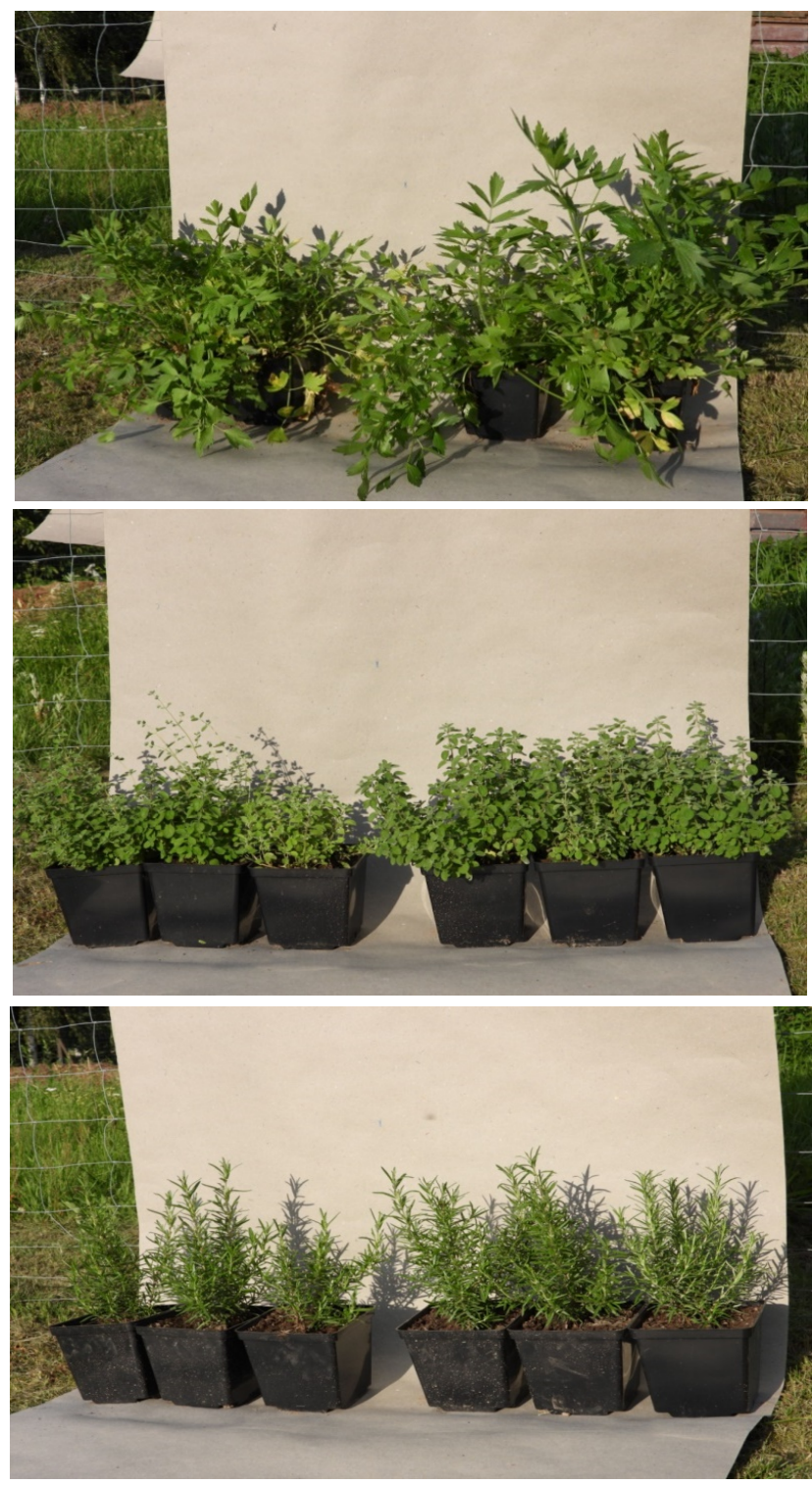

Figure 1. Cont. 


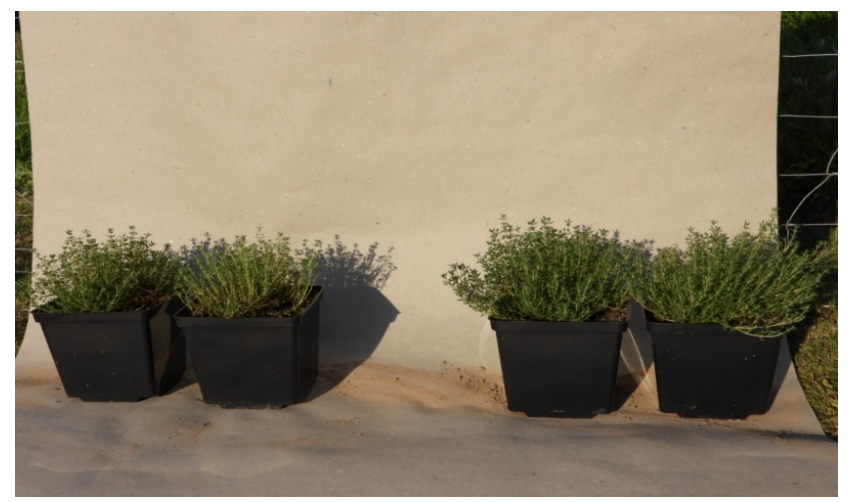

Figure 1. Pot plantation of four herbs (from the top: lovage, marjoram, rosemary and thyme). In these photographs, pots watered with non-treated water and watered with LPGPA are situated on the left and right, respectively).

Evidently, watering with LPGP promoted the growth of those herbs. The data in Table 1 provide quantitative treatment of those observations.

Humidity collected by the growing plants appeared to be practically independent of the kind of water used. LPGPA is known [3] to be a vector transporting species dissolved in it to the tissues. Therefore, ash content in investigated samples increased as a result of an uptake of minerals from the substrate. That uptake was the lowest in case of thyme (Table 1). It was higher by about $7 \%$ than that in cases where the herb was watered with non-treated (control) water. The uptake of minerals by lovage and marjoram watered by LPGPA was almost twice as high.

Watering with LPGPA increased the number of plants by about $50 \%$ in rosemary, and only by $\sim 15 \%$ in thyme. It was paralleled with the height of plants per one tray. It reached increases of about $40 \%$ and only about $25 \%$, respectively. Similarly, the total mass of plants increased by about $21 \%$ and $5.5 \%$ in rosemary and thyme, respectively. Watering with LPGPA promoted an increase in the number of leaves per plant. This was specific for a given herb, with the highest, $\sim 23 \%$, being in thyme and the lowest, $\sim 10 \%$, being in marjoram. Watering with LPGP resulted in a $100 \%$ and only a $10 \%$ increase in the mass of stems in thyme and lovage, respectively. The total mass of foliage was promoted by watering with LPGPA only in the case of lovage and thyme. It increased by $\sim 14$ and $\sim 5 \%$, respectively. This kind of watering had no influence on that parameter for marjoram, and in the case of rosemary, that parameter decreased by $\sim 3 \%$.

Watering with LPGPA had a considerable influence on the composition of essential oils isolated from the herbs (Table 2). Watering with LPGPA increased the yield of that oil solely in the case of lovage.

In every investigated herb, watering with LPGPA offered the possibility of manipulating the composition of their essential oils, and hence, their functional properties. 
Table 1. Characteristics of the planted herbs.

\begin{tabular}{|c|c|c|c|c|c|c|c|c|}
\hline \multirow[b]{2}{*}{ Estimation } & \multicolumn{8}{|c|}{ Herb/Water ${ }^{a}$} \\
\hline & $\begin{array}{l}\text { Lovage } \\
\text { Control }\end{array}$ & $\begin{array}{l}\text { Lovage } \\
\text { LPGPA }\end{array}$ & $\begin{array}{c}\text { Marjoram } \\
\text { Control }\end{array}$ & $\begin{array}{c}\text { Marjoram } \\
\text { LPGPA }\end{array}$ & $\begin{array}{c}\text { Rosemary } \\
\text { Control }\end{array}$ & $\begin{array}{c}\text { Rosemary } \\
\text { LPGPA }\end{array}$ & $\begin{array}{l}\text { Thyme } \\
\text { Control }\end{array}$ & $\begin{array}{l}\text { Thyme } \\
\text { LPGPA }\end{array}$ \\
\hline Number of plants & $14 \pm 0.5$ & $19 \pm 1.0$ & $25 \pm 1.0$ & $34 \pm 0.5$ & $18 \pm 1.0$ & $27 \pm 1.0$ & $39 \pm 0.5$ & $45 \pm 0.5$ \\
\hline Height of plants $/ 1$ pot $[\mathrm{cm}]$ & $28.4 \pm 2.1$ & $36.4 \pm 1.1$ & $12.6 \pm 1.7$ & $17.6 \pm 1.4$ & $16.3 \pm 1.2$ & $26.3 \pm 1.3$ & $7.1 \pm 0.3$ & $8.7 \pm 0.4$ \\
\hline Total mass of plant $[\mathrm{g}]$ & $126.1 \pm 1.3$ & $138.1 \pm 1.5$ & $65.1 \pm 0.5$ & $71.1 \pm 0.3$ & $61.1 \pm 0.3$ & $74.1 \pm 0.2$ & $110.3 \pm 1.5$ & $116.2 \pm 0.7$ \\
\hline Total number of leaves & $42 \pm 2$ & $47 \pm 2$ & $92 \pm 2$ & $103 \pm 2$ & $137 \pm 2$ & $143 \pm 3$ & $224 \pm 1$ & $233 \pm 2$ \\
\hline Number of leaves per plant & $16 \pm 3$ & $19 \pm 3$ & $17 \pm 3$ & $19 \pm 2$ & $11 \pm 2$ & $13 \pm 3$ & $13 \pm 2$ & $16 \pm 2$ \\
\hline Mass of stems [g] & $77.83 \pm 0.14$ & $84.73 \pm 0.13$ & $31.05 \pm 0.16$ & $36.76 \pm 0.12$ & $32.76 \pm 0.12$ & $36.26 \pm 0.12$ & $2.16 \pm 0.12$ & $4.29 \pm 0.12$ \\
\hline Total mass of foliage $[\mathrm{g}]$ & $43.98 \pm 0.23$ & $50.51 \pm 0.22$ & $35.02 \pm 0.28$ & $35.13 \pm 0.28$ & $30.25 \pm 0.32$ & $29.18 \pm 0.19$ & $108.32 \pm 0.12$ & $112.93 \pm 0.62$ \\
\hline Mass of one leaf & $0.334 \pm 0.018$ & $0.338 \pm 0.017$ & $0.121 \pm 0.012$ & $0.127 \pm 0.012$ & $0.094 \pm 0.011$ & $0.097 \pm 0.009$ & $0.213 \pm 0.020$ & $0.214 \pm 0.011$ \\
\hline Humidity [\%] & $11.29 \pm 0.21$ & $11.32 \pm 0.23$ & $9.15 \pm 0.18$ & $9.25 \pm 0.17$ & $8.23 \pm 0.09$ & $8.35 \pm 0.04$ & $6.35 \pm 0.12$ & $6.48 \pm 0.11$ \\
\hline Ash [\%/per $1 \mathrm{~g}$ dry residue] & $1.32 \pm 0.08$ & $1.49 \pm 0.07$ & $1.65 \pm 0.03$ & $1.87 \pm 0.02$ & $1.23 \pm 0.03$ & $1.35 \pm 0.04$ & $1.68 \pm 0.04$ & $1.82 \pm 0.06$ \\
\hline
\end{tabular}

${ }^{a}$ Non-treated water was taken as control. LPGPA denotes water treated in the air.

Table 2. Yield and composition of essential oils extracted from herbs watered with nontreated water (control) and LPGPA.

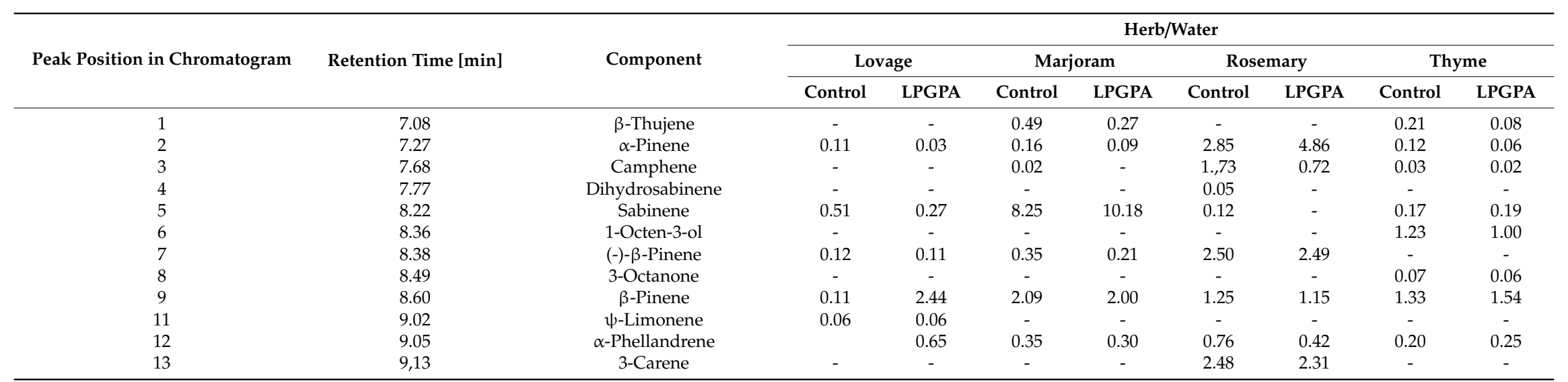


Table 2. Cont

\begin{tabular}{|c|c|c|c|c|c|c|c|c|c|c|}
\hline \multirow{3}{*}{ Peak Position in Chromatogram } & \multirow{3}{*}{ Retention Time [min] } & \multirow{3}{*}{ Component } & \multicolumn{8}{|c|}{ Herb/Water } \\
\hline & & & \multicolumn{2}{|c|}{ Lovage } & \multicolumn{2}{|c|}{ Marjoram } & \multicolumn{2}{|c|}{ Rosemary } & \multicolumn{2}{|c|}{ Thyme } \\
\hline & & & Control & LPGPA & Control & LPGPA & Control & LPGPA & Control & LPGPA \\
\hline 14 & 9.32 & $\alpha$-Terpinene & & 0.05 & 1.67 & 1.56 & 0.27 & 0.23 & 1.92 & 2.34 \\
\hline 17 & 9,63 & D-Limonene & 2.82 & 2.45 & 1.60 & 1.49 & 4.74 & 5.64 & 0.25 & 0.29 \\
\hline 18 & 9.70 & $\beta$-Phellandrene & 20.03 & 17.64 & 2.30 & 2.15 & - & - & - & - \\
\hline 19 & 9.71 & Eucalyptol & - & - & - & - & 12.41 & 9.39 & 0.62 & 0.58 \\
\hline 20 & 9.77 & trans- $\beta$-Ocimene & 0.44 & 1.16 & 0.08 & 0.08 & - & - & - & - \\
\hline 21 & 10.04 & $\beta$-Ocimene & 0.01 & 0.04 & 0.46 & 0.44 & - & - & - & - \\
\hline 23 & 10.67 & cis- $\beta$-Terpineol & - & - & 3.90 & 3.79 & 0.96 & 0.90 & 1.86 & 1.77 \\
\hline 25 & 11.09 & Terpinolene & 0.38 & 0.31 & 0.56 & 0.54 & 2.29 & 1.76 & - & - \\
\hline 26 & 11.32 & 3-Hexen-1-ol, propanoate, (Z)- & - & - & - & - & - & - & 0.09 & 0.07 \\
\hline 27 & 11.40 & Linalool & - & - & - & - & 2.63 & 2.44 & 2.67 & 2.37 \\
\hline 28 & 11.46 & cis-4-Thujanol & - & - & 38.16 & 37.36 & 0.86 & 0.97 & - & - \\
\hline 29 & 11.98 & Chrysanthenone & - & - & - & - & 0.30 & 0.17 & - & - \\
\hline 30 & 12.11 & Neo-allo-ocimene & 0.07 & 0.58 & 0.14 & 0.13 & 0.15 & 0.13 & - & - \\
\hline 31 & 12.24 & Artemiseole & - & - & - & - & 0.09 & - & - & - \\
\hline 32 & 12.50 & trans-(-)-Pinocarveol & - & - & 0.04 & 0.04 & - & - & - & - \\
\hline 33 & 12.51 & cis-Verbenol & - & - & - & - & 0.91 & 1.08 & - & - \\
\hline 34 & 12.63 & Camphor & - & - & - & - & 16.46 & 12.20 & - & - \\
\hline 37 & 13.02 & Pinocarvone & - & - & 0.02 & - & 0.34 & 0.32 & - & - \\
\hline 38 & 13.14 & Camphenol & - & - & - & - & 0.21 & 0.28 & - & - \\
\hline 39 & 13.19 & 1,3-Dimethyl-1-cyclohexene & - & - & - & - & 0.21 & 0.21 & - & - \\
\hline 40 & 13.24 & endo-Borneol-Dup1 & - & - & 0.07 & 0.07 & 7.92 & 10.04 & 0.11 & 0.08 \\
\hline 41 & 13.35 & Isocamphopinone & - & - & - & - & 3.11 & 2.26 & - & - \\
\hline 42 & 13.37 & o-Mentha-1(7),8-dien-3-ol & 0.47 & 0.36 & - & - & - & - & - & - \\
\hline 44 & 13.45 & Terpinen-4-ol & - & - & 0.72 & 1.02 & 0.32 & 0.62 & 0.13 & 0.12 \\
\hline 46 & 13.80 & $\alpha$-Terpineol & 0.13 & 0.13 & 3.11 & 3.18 & 1.05 & 2.63 & 0.10 & 0.10 \\
\hline 47 & 13.84 & Myrtenol & - & - & - & - & 0.29 & 0.36 & - & - \\
\hline 48 & 13.87 & Dihydrocarvone & - & - & 0.14 & - & - & - & - & - \\
\hline 49 & 13.99 & endo-Borneol & - & - & - & - & 0.89 & 0.86 & - & - \\
\hline 50 & 14.04 & trans-Dihydrocarvone & - & - & - & 0.09 & - & - & - & - \\
\hline 51 & 14.11 & cis-Verbenone & - & - & - & - & 15.80 & 14.62 & - & - \\
\hline 54 & 14.91 & trans-Shisool & - & - & - & - & 0.68 & 0.79 & - & - \\
\hline 56 & 14.97 & Carvone & - & - & - & - & 0.03 & - & - & - \\
\hline
\end{tabular}


Table 2. Cont

\begin{tabular}{|c|c|c|c|c|c|c|c|c|c|c|}
\hline \multirow{3}{*}{ Peak Position in Chromatogram } & \multirow{3}{*}{ Retention Time [min] } & \multirow{3}{*}{ Component } & \multicolumn{8}{|c|}{ Herb/Water } \\
\hline & & & \multicolumn{2}{|c|}{ Lovage } & \multicolumn{2}{|c|}{ Marjoram } & \multicolumn{2}{|c|}{ Rosemary } & \multicolumn{2}{|c|}{ Thyme } \\
\hline & & & Control & LPGPA & Control & LPGPA & Control & LPGPA & Control & LPGPA \\
\hline 57 & 15.08 & Dihydrocarveol & - & - & - & - & 1.33 & 1.53 & - & - \\
\hline 59 & 15.08 & Thymoquinone & - & - & - & - & - & - & 0.30 & 0.22 \\
\hline 60 & 15.12 & 4-Terpinenyl acetate & - & - & 11.21 & 12.29 & - & - & - & - \\
\hline 61 & 15.57 & p-Mentha-1,8-dien-3-one & - & - & - & - & 0.30 & 0.41 & - & - \\
\hline 62 & 15.81 & Carveol & - & - & - & - & 2.17 & 0.36 & - & - \\
\hline 64 & 15.92 & Bornyl acetate & 0.05 & - & 0.06 & 0.05 & 5.29 & 9.63 & - & - \\
\hline 66 & 16.04 & Thymol & - & - & - & - & - & - & 59.32 & 58.20 \\
\hline 68 & 16.33 & Carvacrol & - & - & - & - & - & - & 4.26 & 3.90 \\
\hline 70 & 16.81 & Elixene-Dup1 & - & - & 0.07 & 0.06 & - & - & - & - \\
\hline 71 & 17.05 & Elixene & - & - & 0.78 & 0.65 & - & - & - & - \\
\hline 72 & 17.33 & $\alpha$-Terpinyl acetate & 24.38 & 20.76 & - & - & - & - & - & - \\
\hline 74 & 17.53 & Nerol acetate & - & - & 0.10 & - & - & - & - & - \\
\hline 75 & 17.68 & trans-Shisool-Dup1 & - & - & - & - & 0.04 & 0.15 & - & - \\
\hline 77 & 17.96 & Geranyl acetate & 0.23 & 0.06 & 0.17 & 0.16 & - & - & - & - \\
\hline 79 & 18.03 & Copaene & - & - & - & - & 0.13 & - & - & - \\
\hline 82 & 18.97 & Caryophyllene & - & - & 1.53 & 1.30 & 3.75 & 4.89 & 1.45 & 1.16 \\
\hline 83 & 19.14 & $\beta$-Copaene & - & - & - & - & 0.06 & - & - & - \\
\hline 87 & 19.59 & Geranyl propionate & - & - & - & - & - & - & 0.12 & 0.11 \\
\hline 88 & 19.83 & Germacrene D & 0.11 & 0.12 & - & - & - & - & 0.21 & 0.16 \\
\hline 89 & 19.99 & $\gamma$-Elemene & - & - & 0.88 & 0.55 & - & - & - & - \\
\hline 92 & 20.16 & $\gamma$-Cadinene & - & - & - & - & 0.17 & 0.09 & - & - \\
\hline 93 & 20.20 & $\sigma$-Cadinene & - & - & - & - & 0.11 & 0.34 & - & - \\
\hline 95 & 20.80 & Caryophyllene oxide & - & - & - & - & 0.18 & 0.85 & - & - \\
\hline 96 & 21.03 & Cubenol & 0.02 & 0.03 & - & - & - & - & - & - \\
\hline 97 & 21.21 & $\tau$-Cadinol & - & - & - & - & - & - & 0.22 & 0.18 \\
\hline 98 & 21.68 & Butylidenephthalide & 0.30 & 0.46 & - & - & - & - & - & - \\
\hline & 21,75 & cis-Ligustilide & 20.12 & 14.13 & - & - & - & - & - & - \\
\hline \multirow{2}{*}{101.} & 22.10 & trans-Ligustilide & 29.35 & 34.17 & - & - & - & - & - & - \\
\hline & al numer of components & & 23 & 25 & 34 & 30 & 47 & 41 & 26 & 26 \\
\hline \multicolumn{3}{|c|}{ Yield of essential oil [mL/100g dry mass] } & 0.4 & 0.5 & 0.2 & 0.2 & 0.3 & 0.3 & 0.2 & 0.2 \\
\hline
\end{tabular}


Essential oil extracted from lovage watered with the control water contained 23 components residing therein, with a yield of up to $0.10 \%$. Four components, trans-ligustilide, $\alpha$-terpinyl acetate, cis-ligustilide and $\beta$-phellandrene, constituted almost $95 \%$ of the total yield of isolated oil. Ligustilide, a phthalide, is efficient for treating osteoporosis and exhibits other pharmacological activities, such as anti-atherosclerosis, neuroprotection, anticancer, anti-inflammatory and analgesic activities [30,31]. On watering with LPGPA, the content of its trans-and cis-isomers increased and decreased by 6 and $5 \%$, respectively. The content of the second abundant component of that essential oil, $\alpha$-terpinyl acetate, a fragrant compound [32], increased by over $4 \%$. The content of $\beta$-phellandrene, a fragrant cyclic monoterpene [33], decreased by about 3\%. At the same time, the content of D-limonene present originally in the essential oil in the concentration of $2.82 \%$ decreased by less than $0.2 \%$. Watering with LPGPA also resulted in over $2 \%$ increase of the content of $\beta$-pinene and by over $0.6 \%$ the content of $\beta$-ocimene. Additionally, over $3.5 \% \gamma$-terpinene appeared in that oil. In the oil from the control sample, it was absent.

Watering marjoram with LPGPA also considerably changed the composition of essential oil extracted from that plant. The content of the dominating components of the oil, that is, cis-4-thujanol and linalyl acetate, decreased, but the content of 4-terpinenyl acetate and sabinene increased. Sabinene exhibits anti-fungal activity against pathogenic fungi [34].

In essential oil from rosemary dominated camphor, cis-verbenone and eucalyptol. cis-Verbenone is used for insect control [35] and eucalyptol serves as fragrant component, insecticide and repellent [36,37]. Watering with LPGPA generated more cis-verbenol. It is known as an insect pheromone [38].

Watering thyme with LPGPA decreased the content of all important components of the essential oil. Only the content of $\gamma$-terpinene, $\alpha$-terpinene and $\beta$-pinene increased.

It has been documented [3] that in the preparation of LPGPA, the original macrostructure of the water declusterizes into smaller structural units. Moreover, the molecular oxygen dissolved in it is excited from its initial triplet into an excited singlet state. Therefore, excited, unstable oxygen molecules are stabilized by their surrounding with water molecules. This process provides aqueous clathrates hosting singlet oxygen. Additionally, declusterized water better solubilizes various species dissolved in it, for instance, minerals. The size of those clathrates and hydrates of solutes promoted their penetration across the cell membranes. Thus, more efficient supply of the tissues with nutrients and, first of all, with oxygen, took place. The latter could influence the metabolic processes inside the plant tissues not only as an oxidant but also as a donor of energy resulting from the transformation of the excited singlet state back into the triplet state.

\section{Conclusions}

Watering plantations of lovage, marjoram, rosemary and thyme with water treated with low-temperature, low-pressure glow plasma of low frequency appeared to be beneficial for the quality and yield of crops of those herbs. The effects were specific for particular cultivars. In terms of crop yield and quality, water treated with glow plasma performed best in the case of rosemary, and the worst results were observed for thyme. When the yield of essential oils was a criterion, only in the case of lovage did such watering appear beneficial. Watering the remaining herbs did not influence the yield of their essential oils. However, such watering considerably changed the composition of essential oils. These changes were specific for a given herb and involved solely the quantity of particular components of the oils. Only the essential oil from lovage was enriched with a considerable concentration of additional component, $\gamma$-terpinene, which was absent in the oil isolated from the herb watered with control water.

Author Contributions: K.C. run herbs cultivation, W.C. run determination of separation of essential oils, analysis of herbs, T.G. gas chromatographic analyses, Z.O. equipped a research team in nanowater, P.T. invented the project, coordinated study and designed the text of this report. All authors jointly participated in interpretation of all data and in writing report. All authors have read and agreed to the published version of the manuscript. 
Funding: This research did not receive any specific grant from funding agencies in the public, commercial, or not-for-profit sectors

Conflicts of Interest: No conflict of interest is known to the authors.

\section{References}

1. Oszczęda, Z.; Elkin, I.; Stręk, W. Equipment for Treatment of Water with Plasma. Polish Patent PL 216025 B1, 28 February 2014.

2. Reszke, E.; Yelkin, I.; Oszczeda, Z. Plasming Lamp with Power Supply. Polish Patent PL 227530 B1, 26 October 2017.

3. Białopiotrowicz, T.; Ciesielski, W.; Domański, J.; Doskocz, M.; Fiedorowicz, M.; Grąż, K.; Khachatryan, K.; Kołoczek, H.; Kozak, A.; Oszczęda, Z.; et al. Structure and physicochemical properties of water treated with low-temperature low-frequency plasma. Curr. Phys. Chem. 2016, 6, 312-320. [CrossRef]

4. Chwastowski, J.; Ciesielska, K.; Ciesielski, W.; Khachatryan, K.; Kołoczek, H.; Kulawik, D.; Oszczęda, Z.; Tomasik, P.; Witczak, M. Structure and physicochemical properties of water treated under nitrogen with low-temperature glow plasma. Water 2020, 12, 1314. [CrossRef]

5. Ciesielska, K.; Ciesielski, W.; Khachatryan, K.; Kołoczek, H.; Kulawik, D.; Oszczęda, Z.; Tomasik, P. Structure and physicochemical properties of water treated under ammonia with low-temperature glow plasma of low-frequency. Open Chem. 2020, 18, 1-12. [CrossRef]

6. Ciesielska, A.; Ciesielski, W.; Khachatryan, K.; Kołoczek, H.; Kulawik, D.; Oszczęda, Z.; Soroka, J.A.; Tomasik, P. Structure and physicochemical properties of water treated under carbon dioxide with low-temperature glow plasma of low frequency. Water 2020, 12, 1920. [CrossRef]

7. Chwastowski, J.; Ciesielski, W.; Khachatryan, K.; Kołoczek, H.; Kulawik, D.; Oszczęda, Z.; Soroka, J.A.; Tomasik, P.; Witczak, M. Water of increased content of molecular oxygen. Water 2020, 12, 2488. [CrossRef]

8. Ciesielska, A.; Ciesielski, W.; Khachatryan, K.; Kołoczek, H.; Kulawik, D.; Oszczęda, Z.; Soroka, J.A.; Tomasik, P. Structure and physicochemical properties of water treated under methane with low-temperature glow plasma of low frequency. Water 2020, 12, 1638. [CrossRef]

9. Wolski, K.; Talar-Krasa, M.; Leshschenko, A.; Dradrach, A.; Adamczewska-Sowińska, K.; Oszczęda, Z. Application of nanowater and biopreparations in agriculture. Stud. Monogr. Polit. Opolska 2014, 404, 265-372. (In Polish)

10. Pisulewska, E.; Ciesielski, W.; Jackowska, M.; Gąstoł, M.; Oszczęda, Z.; Tomasik, P. Effect of water treated with low-pressure, low-temperature glow plasma of low frequency on planted peppermint (Mentha piperita). EJPAU Ser. Biotechnol. 2018, 21. [CrossRef]

11. Ciesielska, K.; Ciesielski, W.; Kulawik, D.; Oszczęda, Z.; Tomasik, P. Cultivation of cress involving water treated under different atmospheres with low-temperature, low-pressure glow plasma of low frequency. Water 2020, 12, 2152. [CrossRef]

12. Ciesielska, K.; Ciesielski, W.; Girek, T.; Kołoczek, H.; Oszczęda, Z.; Tomasik, P. Reaction of Lavandula angustifolia Mill. to water treated with low-temperature, low- pressure glow plasma of low frequency. Water 2020, 12, 3168. [CrossRef]

13. Ciesielski, W.; Gąstoł, M.; Girek, T.; Kulawik, D.; Oszczęda, Z.; Pisulewska, E.; Tomasik, P. Specific controlling essential oil composition of basil (Ocimum basilicum L.). Water 2020, 12, 3332. [CrossRef]

14. Ciesielski, W.; Gąstoł, M.; Girek, T.; Kulawik, D.; Oszczęda, Z.; Pisulewska, E.; Tomasik, P. Specific modulation of flavor and aroma of Greek oregano (Origanum vulgare) and its essential oil. Water 2020, submitted.

15. Downie, S.R.; Plunkett, G.M.; Watson, M.F.; Spalik, K.; Katz-Downie, D.S.; Valiejo-Roman, C.M.; Terentieva, E.I.; Troitsky, A.V.; Lee, B.-Y.; Lahham, J.; et al. Tribes and clades within Apiaceae subfamily Apioideae: The contribution of molecular data. Edin. J. Botany 2001, 58, 301-330. [CrossRef]

16. Huxley, A. New RHS Dictionary of Gardening; Macmillan: London, UK, 1992; ISBN 0-333-47494-5.

17. Ashwood-Smith, M.J.; Ceska, O.; Yeoman, A.; Kenny, P.G. Photosensitivity from harvesting lovage (Levisticum officinale). Contact Derm. 1993, 26, 356-357. [CrossRef] [PubMed]

18. European Medicines Agency. Community Herbal Monograph on Levisticum Officinale Koch, Radix, 2012-03-27; European Medicines Agency: Amsterdam, The Netherlands, 2012.

19. Marjoram, H. Food Reference. 2017. Available online: http://www.foodreference.com/html/tmarjoram. htmlhttp://www.foodreference.com/html/tmarjoram.html (accessed on 20 October 2020). 
20. Burlando, B.; Verotta, L.; Cornara, L.; Bottini-Massa, E. Herbal Principles in Cosmetics Properties and Mechanisms of Action; CRC Press: Boca Raton, FL, USA, 2010; p. 303. ISBN 978-1-4398-1214-3.

21. Vallverdú-Queralt, A.; Regueiro, J.; Martínez-Huélamo, M.; Rinaldi Alvarenga, J.F.; Leal, L.N.; Lamuela-Raventos, R.M. A comprehensive study on the phenolic profile of widely used culinary herbs and spices: Rosemary, thyme, oregano, cinnamon, cumin and bay. Food Chem. 2014, 154, 299-307. [CrossRef] [PubMed]

22. Daniells, S. Oregano, Rosemary Extracts Promise Omega-3 Preservation. Food Navigator, 20 November 2017.

23. Easter, M. International Thymus Register and Checklist; BPR Publishers: London, UK, 2009; ISBN 0956339808.

24. Grieve, M. Thyme. A Modern Herbal. Available online: https://botanical.com/botanical/mgmh/t/thygar16. html (accessed on 15 November 2020).

25. PDR for Herbal Medicine. Thymus Vulgaris; Medical Economics Company: Montvale, NJ, USA, $2020 ;$ p. 1184. Available online: http://snst-hu.lzu.edu.cn/zhangyi/ndata/Thyme.html (accessed on 20 October 2020).

26. Borugă, O.; Jianu, C.; Mişcă, C.; Goleț, I.; Gruia, A.; Horhat, F. Thymus vulgaris essential oil: Chemical composition and antimicrobial activity. J. Med. Life 2014, 7, 56-60.

27. Pierce, A. American Pharmaceutical Association Practical Guide to Natural Medicines; Stonesong Press: New York, NY, USA, 1999; pp. 338-340.

28. Tawfik, S.S.; Abbady, M.I.; Zahran, A.M.; Abouelalla, A.M.K. Therapeutic efficacy attained with thyme essential oil supplementation throughout $\gamma$-irradiated rats. Egypt. J. Rad. Sci. Applic. 2006, 19, 1-22.

29. Duncan, D.B. Multiple range and multiple F tests. Biometrics 1955, 11, 1-42. [CrossRef]

30. Tisserand, R.; Young, R. Essential Oil Profiles. In Essential Oil Safety; Elsevier Ltd.: Amsterdam, The Netherlands, 2014; Chapter 13.

31. Yang, F.; Lin, Z.W.; Huang, T.Y.; Chen, T.T.; Cui, J.; Li, M.Y.; Hua, Y.Q. Ligustilide, amajor bioactive component of Angelica sinensis, promotes bone formation viathe GPR30/EGFR pathway. Sci. Rep. 2019, 9, 6991. [CrossRef]

32. Braun, N.A.; Meier, M. $\delta$-Terpinyl acetate. A new natural component from the essential leaf oil of L. (Lauraceae). J. Ess. Oil Res. 2001, 13, 95-97. [CrossRef]

33. Boland, D.J.; Brophy, J.J.; House, A.P.N. Eucalyptus Leaf Oils; Inkata Press: Melbourne, Australia, 1991; ISBN 0-909605-69-6.

34. Arunkumar, R.; Nair, S.A.; Rameshkumar, K.B.; Subramoniam, A. The essential oil constituents of Zornia diphylla (L.) Pers, and anti-inflammatory and antimicrobial activities of the oil. Rec. Nat. Prod. 2014, 8, 385-393.

35. U.S. Environmental Protection Agency. Pesticide Fact Sheet \#128986. Available online: http://npic.orst.edu/ npicfact.htm (accessed on 20 October 2020).

36. Klocke, J.A.; Darlington, M.V.; Balandrin, M.F. 8-Cineole (Eucalyptol), a mosquito feeding and ovipositional repellent from volatile oil of Hemizonia fitchii (Asteraceae). J. Chem. Ecol. 1987, 13, 2131-2141. [CrossRef] [PubMed]

37. Sfara, V.; Zerba, E.N.; Alzogaray, R.A. Fumigant insecticidal activity and repellent effect of five essential oils and seven monoterpenes on first-instar nymphs of Rhodnius prolixus. J. Med. Entomol. 2009, 46, 511-515. [CrossRef] [PubMed]

38. Jakus, R.; Blazenec, M. Influence of proportion of (4S)-cis-verbenol in pheromone bait on Ips typographus (Co., Scolytidae) catch in pheromone trap barrier and in single trap. J. Appl. Entomol. 2002, 126, 306-311. [CrossRef]

Publisher's Note: MDPI stays neutral with regard to jurisdictional claims in published maps and institutional affiliations.

(C) 2020 by the authors. Licensee MDPI, Basel, Switzerland. This article is an open access article distributed under the terms and conditions of the Creative Commons Attribution (CC BY) license (http://creativecommons.org/licenses/by/4.0/). 